Ephraim Meir

Interreligious Theology 



\section{Ephraim Meir}

Interreligious

Theology

Its Value and Mooring in Modern Jewish Philosophy 
This book was made possible through the generosity of the Veronika and Volker Putz Foundation, that sponsored my various stays at the Academy of World Religions at the University of Hamburg in the framework of the Emmanuel Levinas guest professorship for Jewish Dialogue Studies and Interreligious Theology.

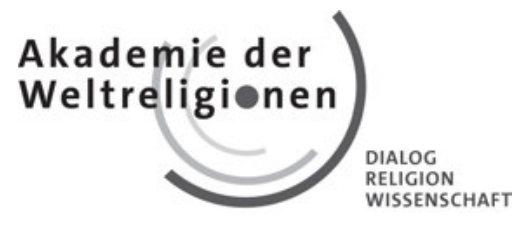

ISBN 978-3-11-043931-1

e-ISBN (PDF) 978-3-11-043045-5

e-ISBN (EPUB) 978-3-11-043051-6

\section{Library of Congress Cataloging-in-Publication Data}

A CIP catalog record for this book has been applied for at the Library of Congress.

\section{Bibliographic information published by the Deutsche Nationalbibliothek}

The Deutsche Nationalbibliothek lists this publication in the Deutsche Nationalbibliografie; detailed bibliographic data are available in the Internet http://dnb.dnb.de.

(C) 2015 Walter de Gruyter GmbH, Berlin/Boston

\& Hebrew University Magnes Press, Jerusalem

Typesetting: Michael Peschke, Berlin

Printing: CPI books GmbH, Leck

@ Gedruckt auf säurefreiem Papier

Printed in Germany

www.degruyter.com

www.magnespress.co.il 
To Veronika and Volker Putz 
